\title{
Common Weedy Plants on Open, Tilled, and Rocky Soil in the Redland Agricultural Area, Miami-Dade County, Florida'
}

\author{
Cliff G. Martin and Zachary T. Brym²
}

This article provides a reference for the most competitive weeds found in south Florida open areas with Rockdale soil. The Redland agricultural area to the west and southwest of Miami grows vegetables in the Rockdale soil, which receives regular cultivation and tillage. The region has a humid subtropical climate with hot, humid summers; noticeably cooler, drier winters; a wet season from May to October; a mean annual temperature of $23.3^{\circ} \mathrm{C}\left(74^{\circ} \mathrm{F}\right)$; and $1420 \mathrm{~mm}$ (56 inches) of annual rainfall. The poor, dry, and rocky soils, which are typified by Krome gravelly loam, are unique to Miami-Dade County, Monroe County, and parts of Broward County. Prominent field crops grown in the cooler months include tomatoes, squash, and snap beans; okra is grown in the warmer months. High-value crops, such as tomatoes and squash, are frequently grown with drip irrigation under plastic mulch that covers raised beds to help control weeds. The environment for field crop weeds is typically open, tilled at least once annually, and may or may not be irrigated. These sites may or may not be adjacent to or within beds of plastic mulch. By using this guide, the farmer, Master Gardener, or home grower will be able to recognize weeds that are most common and economically competitive with crops and native vegetation in south Florida. Early detection can help with management programs that effectively control weed populations.

\section{Weeds That Break through Plastic Mulch}

Plastic mulch is frequently used to control weeds in south Florida, especially for vegetable crops. Within the mulched beds, some weeds regularly break through the plastic and are grouped as "hole-puncher" weeds in this guide. By creating holes in the plastic, hole-puncher weeds tend to be more destructive because they reduce the effectiveness of plastic barriers for weed control. Notable hole-puncher weed species include the nutsedges (Cyperus rotundus $\mathrm{L}$. and C. esculentus L.) and broadleaf woodsorrel (Oxalis latifolia Kunth).

\section{Purple Nutsedge, Cyperus rotundus, and Yellow Nutsedge, $C$. esculentus (Cyperaceae)}

Purple and yellow nutsedges are native to Asia, Africa, and Europe. They are common, troublesome weeds in highly disturbed, open areas. With the prohibition of methyl bromide for pest control, nutsedges have become more problematic during the last $10-15$ years.

1. This document is SS-AGR-459, one of a series of the Agronomy Department, UF/IFAS Extension. Original publication date January 2022. Visit the EDIS website at https://edis.ifas.ufl.edu for the currently supported version of this publication.

2. Cliff G. Martin, research associate; and Zachary T. Brym, assistant professor, Agronomy Department; UF/IFAS Tropical Research and Education Center, Homestead, FL 33031.

The Institute of Food and Agricultural Sciences (IFAS) is an Equal Opportunity Institution authorized to provide research, educational information and other services

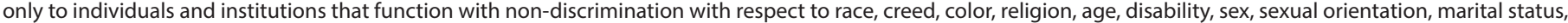

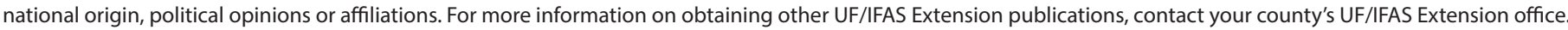
U.S. Department of Agriculture, UF/IFAS Extension Service, University of Florida, IFAS, Florida A \& M University Cooperative Extension Program, and Boards of County Commissioners Cooperating. Andra Johnson, dean for UF/IFAS Extension. 


\section{Growth Habit}

Each plant usually forms a basal rosette with a single stem emerging from a small underground corm-like tuber (nutlet); this is a short, swollen, bulblike stem base that often resembles a thick root. It spreads through the soil by thin, wiry, underground stems (rhizomes), which are slightly thicker than roots. Plants are up to $50 \mathrm{~cm}$ tall $(19.7$ in) with reddish spikelets (purple nutsedge) or up to $70 \mathrm{~cm}$ (27.6 in) with yellow-brown spikelets (yellow nutsedge).

\section{Leaves}

Leaves are arcing, fluted, often reddish near the base, and up to $40 \mathrm{~cm}$ (15.7 in) long (purple nutsedge), or $60 \mathrm{~cm}(23.6$ in) and yellowish (yellow nutsedge). Leaf tips of yellow nutsedge are often longer and more attenuated than on purple nutsedge.

\section{Inflorescence}

Purple and yellow nutsedges have similar inflorescences. Each plant produces a long stalk (peduncle) topped with 3-10 spikes (5-130 $\mathrm{mm}$ ), each holding loosely arranged spikelets $(5-40 \mathrm{~mm})$. These are packed with 1- to 2-mm scales, each containing a single, highly reduced flower.

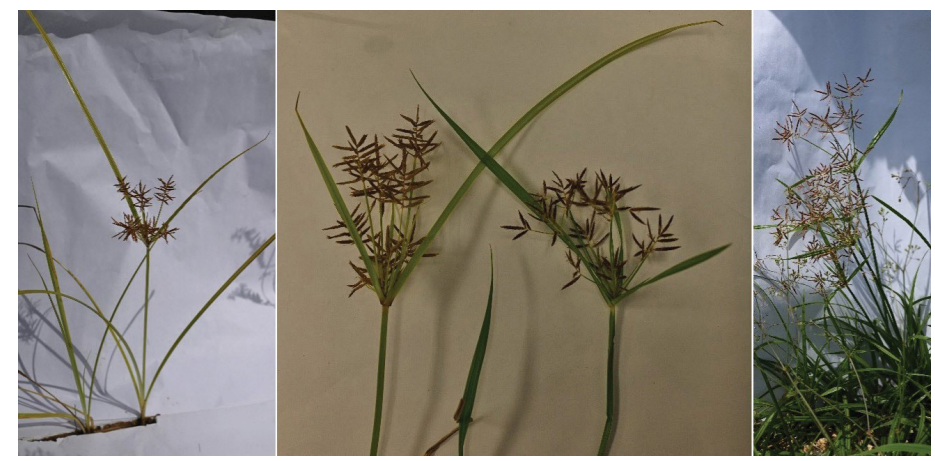

Figure 1. Left: Yellow nutsedge (C. esculentus). Center: Close-up of yellow nutsedge (left) with more elongate and yellowish foliage than purple nutsedge (right). Right: Purple nutsedge (Cyperus rotundus). Credits: Kingsley Wiggan

\section{Broadleaf Woodsorrel, Oxalis Iatifolia (Oxalidaceae)}

This native plant of the West Indies and Mexico can be extremely abundant in southern Florida in open rocky soil.

\section{Growth Habit}

This plant is perennial with leaves and flower clusters to 35 $\mathrm{cm}$ arising from clustered bulbs. It also develops a thick taproot on larger plants. Plants are relatively small compared to many aggressive species, such as ragweed parthenium, but they can be more locally abundant.

\section{Leaves}

Three leaflets (3-30 $\mathrm{mm}$ long by 4-60 $\mathrm{mm}$ wide), each with an inverse-triangular shape, attach to a common point on the top of the petiole.

\section{Inflorescence}

Inflorescence consists of attractive, 1- to 4-cm-wide clusters (umbels) of 6-16 flowers. Each flower $(8-12 \mathrm{~mm}$ ) is lavender with a yellow center and is on a 3 - to 20 - mm stalk (pedicel), which attaches to a peduncle (up to $35 \mathrm{~cm}$ ).

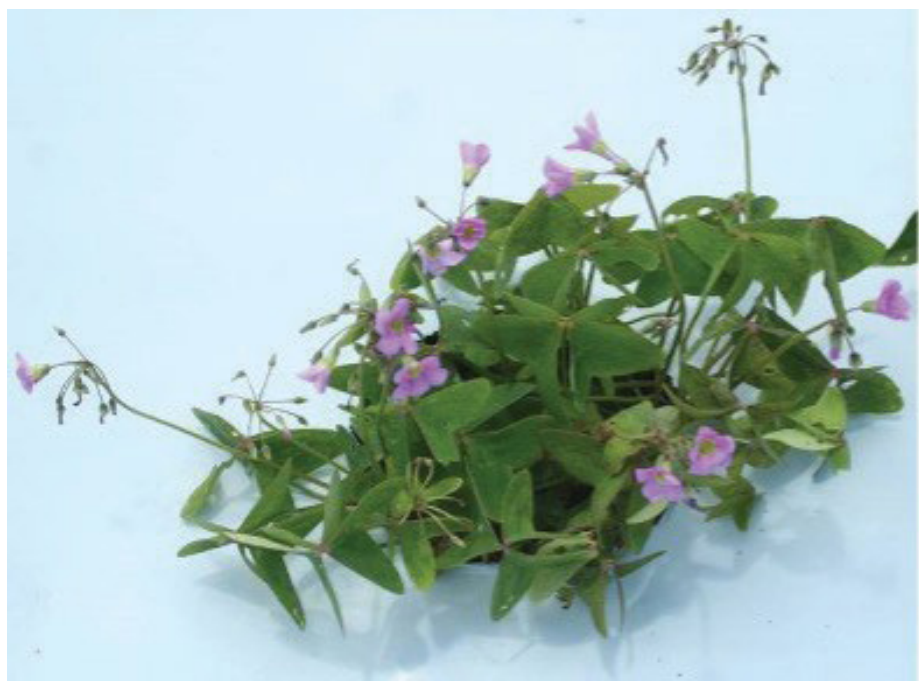

Figure 2. Broadleaf woodsorrel (Oxalis latifolia). Credits: Cliff Martin

\section{Weeds That Do Not Break through Plastic Mulch}

The remaining weed species in this guide do not readily break through plastic mulch. These weeds grow in open areas, such as row-middles and holes in plastic sheeting. Although plastic may be especially effective in controlling the non-hole-puncher weeds, these species opportunistically fill remaining open spaces. They are often faster-growing, larger, and more aggressive than hole-puncher weeds in choking out crop plants.

\section{Spiny Amaranth, Amaranthus spinosus L. (Amaranthaceae)}

Spiny amaranth or spiny pigweed, a native of tropical America, is very common throughout Florida. It is very troublesome because of its abundance, steadfast root system, and sharp stem spines, which often make handpulling very difficult and painful. Spiny amaranth is often one of the first weed species to appear after spring crops are harvested and the fields are disk-tilled and left fallow. Seeds germinate throughout the summer months, and each 
rainfall event triggers another green flush of seedlings. Because of the high germination rate and a copious amount of seeds produced, control measures such as hand-pulling may only last a few weeks before new seedlings blanket an area.

\section{Growth Habit}

This summer annual grows to $1 \mathrm{~m}$ tall with an irregular, erect-to-spreading growth habit. It can produce over 100,000 seeds.

\section{Leaves}

Leaves are ovate and triangular to rhombic with blades 1-6 $\mathrm{cm}$ long $\mathrm{x} 0.5-4 \mathrm{~cm}$ wide, often with a lighter green patch or arc across the width of the top surface. The leaf stem (petiole) is about a third to half the length of the blade.

\section{Inflorescence}

Inflorescence is dense, greenish-white, and irregular. Terminal spikes $(2-20 \mathrm{~cm})$ are often conspicuously longer than the axillary spikes $(0.5-4 \mathrm{~cm})$. Flowers are green and white, scaly, $2-2.5 \mathrm{~mm}$, and surrounded by $3-\mathrm{mm}$ bracts (also green, white, and scaly).

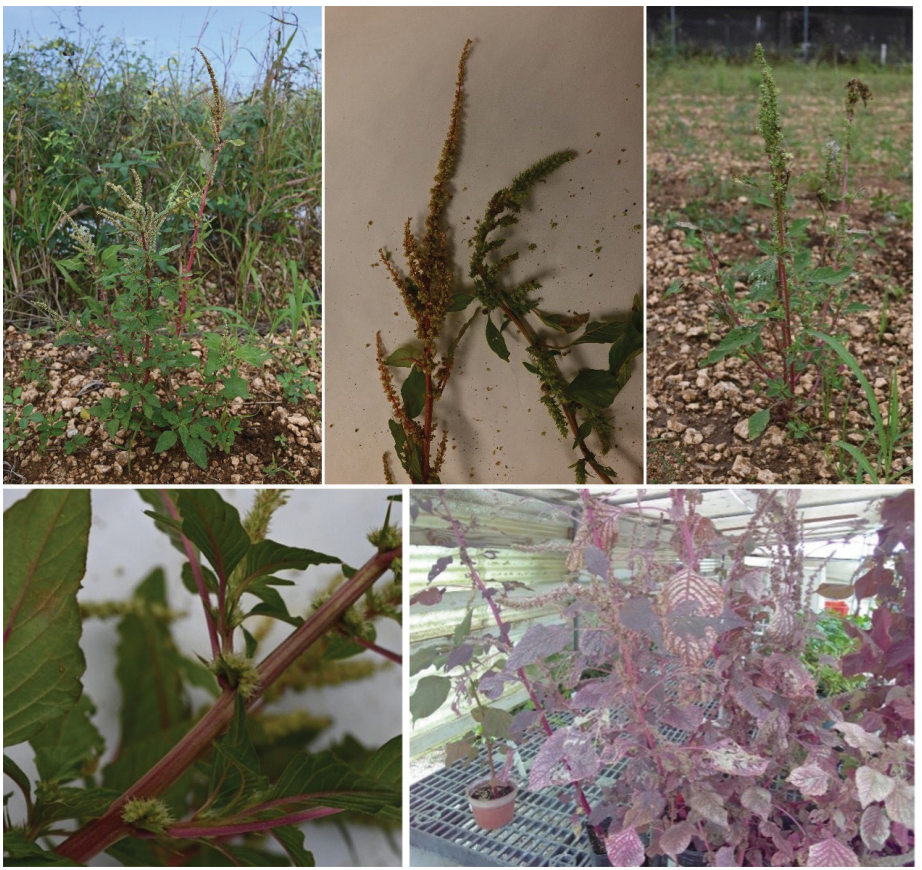

Figure 3. Top left: Spiny amaranth (Amaranthus spinosus). Top center: Flowers of spiny amaranth (left) and smooth pigweed (right). Top right: Smooth pigweed (Amaranthus hybridus). Bottom left: Spines along the stem of spiny amaranth, which are not present on smooth pigweed. Spiny amaranth also has slightly smaller floral bracts and a less "hairy" appearance. Bottom right: Smooth pigweed in the red form (with melonworm infestation).

Credits: Kingsley Wiggan (top and bottom left) and Cliff Martin (bottom right)

\section{Smooth Pigweed, Amaranthus hybridus L. (Amaranthaceae)}

Smooth pigweed is native to the southwestern US and tropical America where it rapidly grows into a large, dense, irregular mass of foliage. A common alternate color form (perhaps 1 in 1,000 seedlings) produces reddish pigmentation in the leaves and stems. These reddish plants are attractive, and along with the non-pigmented plants, have edible seeds and foliage. They are often consumed as a leafy vegetable or grain by indigenous people and others in countries such as Mexico and Bangladesh. The foliage of smooth pigweed is also a notable food source for melonworms, mites, and possibly other agronomic and vegetable pests.

\section{Growth Habit}

This summer annual grows up to $1.8 \mathrm{~m}(6 \mathrm{ft})$ tall. It is one of the largest herbaceous field weeds in the Redland agricultural area.

\section{Leaves}

Leaves are ovate to lanceolate and triangular to rhombic with blades $1.5-7 \mathrm{~cm}$ long $\mathrm{x} 0.5-4 \mathrm{~cm}$ wide. Leaves resemble those on spiny amaranth except without the accompanying spines and often with a more wrinkled appearance.

\section{Inflorescence}

Although similar to spiny amaranth, common pigweed tends to show greater uniformity between its terminal and lateral spike-like panicles. Individual flowers resemble spiny amaranth blooms, except the surrounding bracts are often slightly longer and more pointed; hence, the inflorescence can appear hairier.

\section{False Daisy, Eclipta prostrata (L.) (Asteraceae)}

This unattractive native species is most common in the wetter parts of the field, often due to excessive irrigation. Plastic mulch often improves the retention of water, thereby enhancing the growth and abundance of false daisies near the plastic. Similar to other weeds in this environment, false daisies often grow very quickly during the warmer months.

\section{Growth Habit}

This is a warm-season annual with prostrate to erect stems growing to $60 \mathrm{~cm}$, which produce roots at the nodes. 


\section{Leaves}

Leaves are opposite and 1-9 cm long. They are linear, lanceolate, or elliptical, rough-hairy but with smooth (entire) or toothed margins.

\section{Inflorescence}

The white-and-green flower heads occur in groups of 1-3 in leaf axils and have 10 - to $30-\mathrm{mm}$ peduncles. Each flower head is 3.5-6 mm wide when blooming, but enlarges to 6-9 $\mathrm{mm}$ in fruit. The flower head contains white ray flowers with strap-shaped corollas $(3-3.5 \mathrm{~mm})$ along the edges, and symmetrical, tubular, white disk flowers $(2.5-3 \mathrm{~mm})$ in the interior. About half the length of each flower is composed of the white corolla.
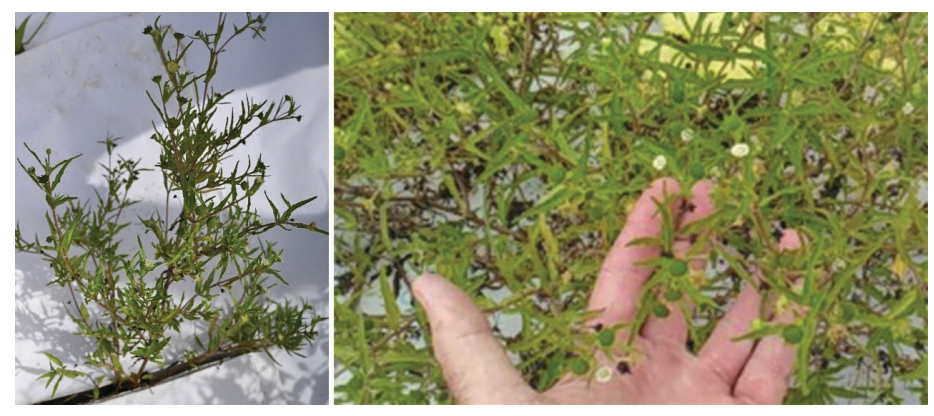

Figure 4. False daisy (Eclipta prostrata).

Credits: Kingsley Wiggan (left) and Cliff Martin (right)

\section{Ragweed Parthenium, Parthenium hysterophorus L. (Asteraceae)}

Also known as parthenium weed, Santa Maria, feverfew, congress grass, carrot weed, or white top, this abundant species is native to Mexico and Central and South America. Widely introduced into other countries worldwide, ragweed parthenium is an invasive species that poses serious problems in Africa and India, and is increasingly troublesome in Florida. It exhibits allelopathy towards other plant species and causes allergic reactions in humans. Ragweed parthenium resembles and is often confused with common ragweed (Ambrosia artimisiifolia L.). However, common ragweed has only tubular disk flowers, while ragweed parthenium has both tubular disk and strap-shaped ray flowers. Ragweed parthenium is infamously resistant to herbicides such as Roundup (glyphosate) and is often difficult to manage.

\section{Growth Habit}

This plant is an annual; it is herbaceous and seed-propagated, with each plant producing 2,400-30,000 seeds. The young plants form a basal rosette with leaves up to $25 \mathrm{~cm}$ long. Plants may later reach $2 \mathrm{~m}$ tall with paniculate, hairy (pubescent) branches marked with lengthwise grooves.

\section{Leaves}

Leaves are finely lobed and pinnatifid to bipinnatifid. Leaf length is highly variable $(\sim 1-25 \mathrm{~cm})$.

\section{Inflorescence}

Each plant can have hundreds of greenish-white flower heads ( $3 \mathrm{~mm}$ by $3 \mathrm{~mm}$ ). The five outer, fertile flowers (2-3 $\mathrm{mm}$ long) have strap-shaped corollas $(0.5-1 \mathrm{~mm})$, while the inner, sterile disk flowers (1-2.5 mm long) have symmetrical, tubular corollas (also $0.5-1 \mathrm{~mm}$ ). Upper parts of the flowers are white, while remainders of the flower heads are greener.

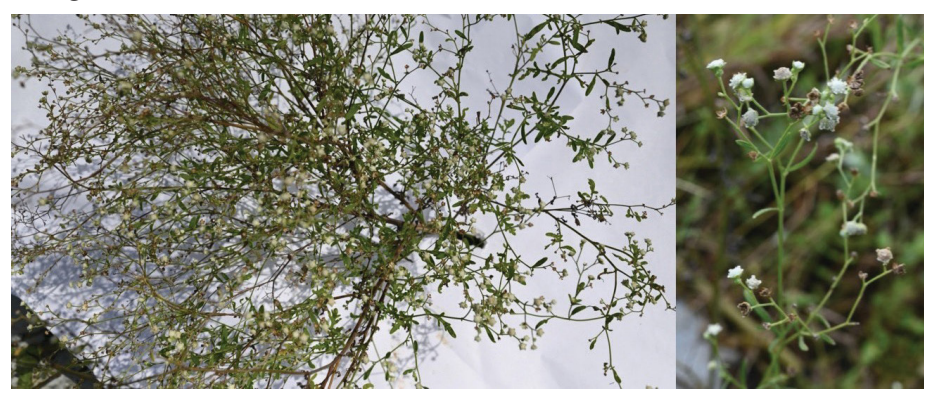

Figure 5. Ragweed parthenium (Parthenium hysterophorus). Credits: Kingsley Wiggan

\section{Hyssopleaf Sandmat, Euphorbia [Chamaesyce] hyssopifolia (L.) Small (Euphorbiaceae)}

This common native weed is very similar in appearance, habitat, and abundance to the graceful sandmat, $E$. hypericifolia (L.) Millsp. However, the graceful sandmat is more common in less-disturbed habitats such as partially shaded landscape beds. In the Redland agricultural area, the hyssopleaf sandmat appears to be somewhat more common than the graceful sandmat in open, tilled, and often irrigated fields. In hyssopleaf sandmat, the hairlike bracts (stipules) on the stem between opposite leaves are small or absent $(\leq 0.5 \mathrm{~mm})$ but are $1-1.5 \mathrm{~mm}$ long on the graceful sandmat. More subtle, commonly seen differences include the tendency of hyssopleaf sandmat to have less showy flowers and a slightly less upright growth habit than the graceful sandmat.

\section{Growth Habit}

This is an erect or ascending annual with smooth stems (to $1 \mathrm{~m}$ ), which have milky sap and branch abundantly from the upper nodes. 


\section{Leaves}

Leaves are oblong, ovate, obovate, or lanceolate, with lopsided bases and finely toothed (serrate) margins. They are 3-25 mm long x 1-10 mm wide.

\section{Inflorescence}

In the upper branches, clusters of 1-mm white flowers give way to $1.3-$ to $1.8-\mathrm{mm}$ capsules, which are hairless, threelobed, and three-seeded.

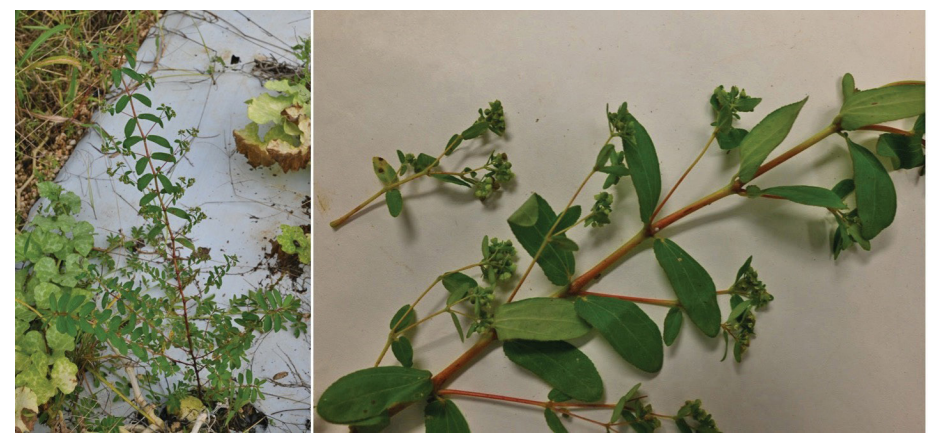

Figure 6. Hyssopleaf sandmat (Euphorbia [Chamaesyce] hyssopifolia). Credits: Kingsley Wiggan

\section{Wild Bush Bean, Macroptilium lathyroides (L.) Urb. (Fabaceae)}

This introduced species from tropical America yields attractive, dark red flowers and is troublesome on two fronts. It is an aggressive weed in highly disturbed, open areas and an alternate host for viruses that attack snap beans (Phaseolus vulgaris L.), including bean golden yellow mosaic virus.

\section{Growth Habit}

This sprawling herb grows to $1 \mathrm{~m}$ and is often somewhat vining.

\section{Leaves}

Leaves are trifoliate with leaflets $10-50 \mathrm{~mm}$ long x 3-20 $\mathrm{mm}$ wide; these are often bluish-green and can be rhombic, triangular, ovate, oblong, lanceolate, or linear. However, virus-infected leaves show gold mottling symptoms similar to those on snap beans.

\section{Inflorescence}

Flower spikes (5-45 cm long) yield 2-15 dark red, 15- to 30 -mm flowers, followed by thin, cylindrical fruits (25-100 $\mathrm{mm}$ long by $2.5-3.5 \mathrm{~mm}$ thick).

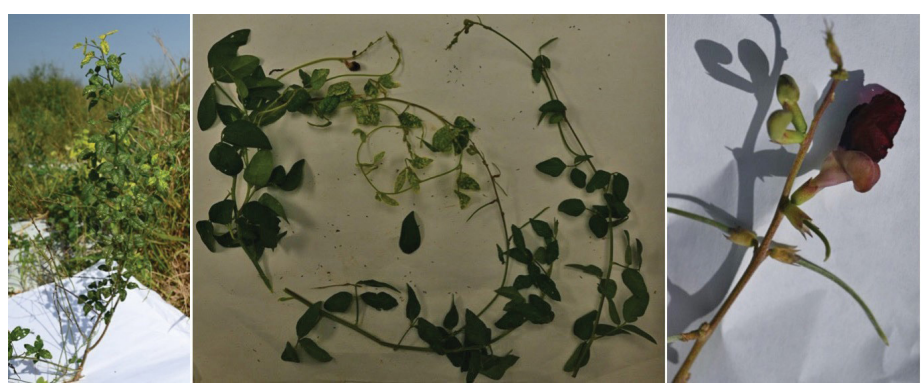

Figure 7. Wild bush bean (Macroptilium lathyroides). Credits: Kingsley Wiggan

\section{Cutleaf Evening Primrose, Oenothera laciniata Hill (Onagraceae)}

This native, fast-growing herb can blanket the ground with a mat-like growth, especially near irrigated beds in the spring.

\section{Growth Habit}

This is a fast-growing, prostrate, winter annual or shortlived perennial. Branches and fibrous roots attach mainly at the oldest parts of the stem (base).

\section{Leaves}

Leaves are alternate, lanceolate to elliptical, and 1-6 cm long, with irregularly notched or lobed (laciniate) margins.

\section{Inflorescence}

Yellow to reddish flowers (3-4 cm total length, 1-1.5 $\mathrm{cm}$ corolla) develop singly in the leaf axils; they become cylindrical, four-ribbed capsules (25-50 mm long x 2-3 mm wide).

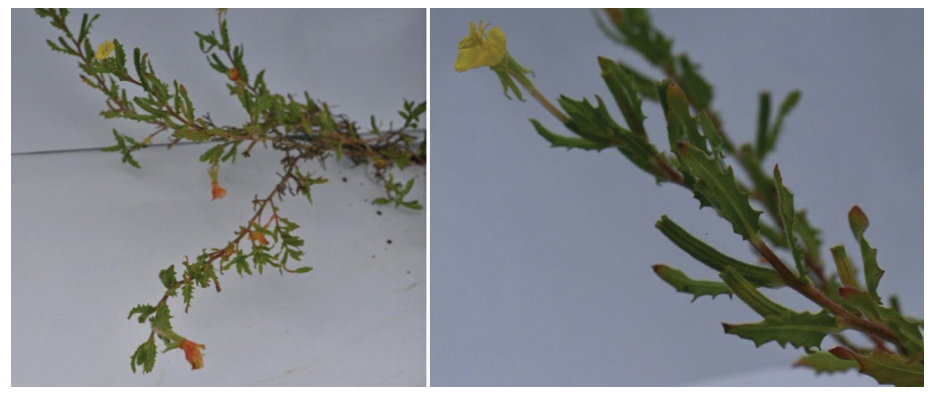

Figure 8. Cutleaf evening primrose (Oenothera laciniata). Credits: Kingsley Wiggan

\section{Southern Crabgrass, Digitaria ciliaris (Retz.) Koeler (Poaceae)}

Southern crabgrass is common, native, and has great plasticity or flexibility allowing endurance to different environmental conditions. It is one of the most aggressive 
and conspicuous species in the Redland agricultural area and quickly takes advantage of any holes or tears in the plastic mulch. In lawns, it is also very common, and it often appears more prostrate with smaller leaves and inflorescences than in open, more frequently tilled locations. Inflorescence branches on these prostrate plants often will remain smaller and "shut" (appressed together) compared with plants in the full sun or in deeper, more fertile soils. Given its highly plastic growth habit and short generations, decades of mowing may be selecting it into a more prostrate form with smaller inflorescences. The poor, shallow rocky soils or partial shading present in many lawns, compared with the open conditions and deeper soils of cultivated fields, may also be factors.

Southern crabgrass (Digitaria ciliaris) now includes the large crabgrass (D. sanguinalis $L$.) as a synonym. The invasive East Indian crabgrass (D. setigera Roth ex Roem. \& Schult.) can be distinguished from southern crabgrass by its first glume (bract) on the spikelet; this is absent or up to $0.1 \mathrm{~mm}$ long compared with $0.2-0.8 \mathrm{~mm}$ on southern crabgrass. East Indian crabgrass also has more uniformsized foliage and inflorescences and is considerably less common than southern crabgrass. Otherwise, the two species intermingle in the Redland agricultural area, look nearly identical, and may be interbreeding. The distinction between southern crabgrass and East Indian crabgrass is technically challenging, although both species can be treated and managed similarly.

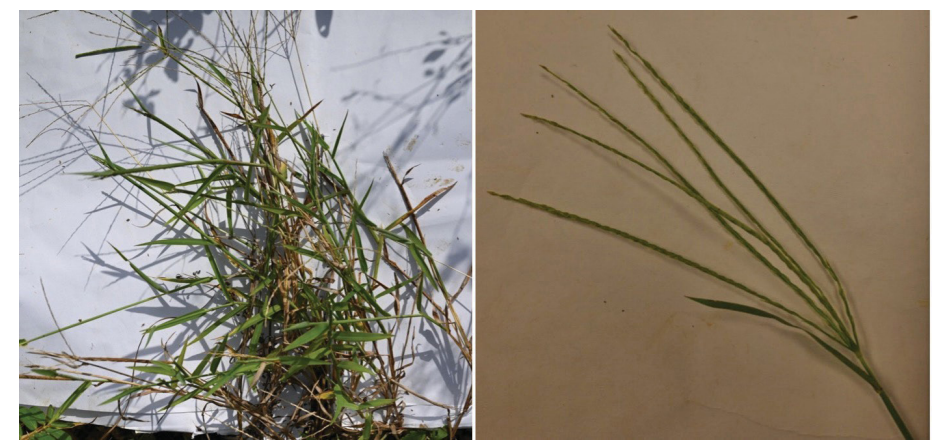

Figure 9. Southern crabgrass (Digitaria ciliaris).

Credits: Kingsley Wiggan

\section{Growth Habit}

Typically an annual, the tufted, spreading-to-prostrate stems (to $1 \mathrm{~m}$ ) often produce roots at the stem nodes.

\section{Leaves}

Blades are 1-20 $\mathrm{cm}$ long and 3-7 $\mathrm{mm}$ wide with hair (pubescence) on both sides of the blade and on the outer side of the sheath.

\section{Inflorescence}

The inflorescence axis $(4-50 \mathrm{~cm})$ yields $2-12$ spike-like branches (each 1-15 cm long), which arise singly or in groups from different axis locations; the $3-\mathrm{mm}$ spikelets are paired and have 1- to 3-mm peduncles.

\section{Jungle Rice, Echinochloa colona (L.) Link (Poaceae)}

Jungle rice is native to regions of Asia, Europe, and/or Africa. It is cosmopolitan in the tropics and subtropics and widely distributed within temperate regions, such as the US. Typical habitats include open, wet disturbed sites, such as ditches and irrigated fields.

\section{Growth Habit}

This is a summer annual growing to $1 \mathrm{~m}$ tall with erect to spreading hairless branches.

\section{Leaves}

Blades are 2-40 cm long; sheaths and blades are smooth, hairless, and without a membrane (ligule) at the base of the leaf between the upper blade and inner sheath.

\section{Inflorescence}

The 5-25 short branches (8-30 mm long) occur alternately on the 5- to 50-cm-long main axis. They are appressed to the stem or spreading and have four evenly spaced rows of fruits $(2.1-2.5 \mathrm{~mm})$ with pointed tips (semi-awned).

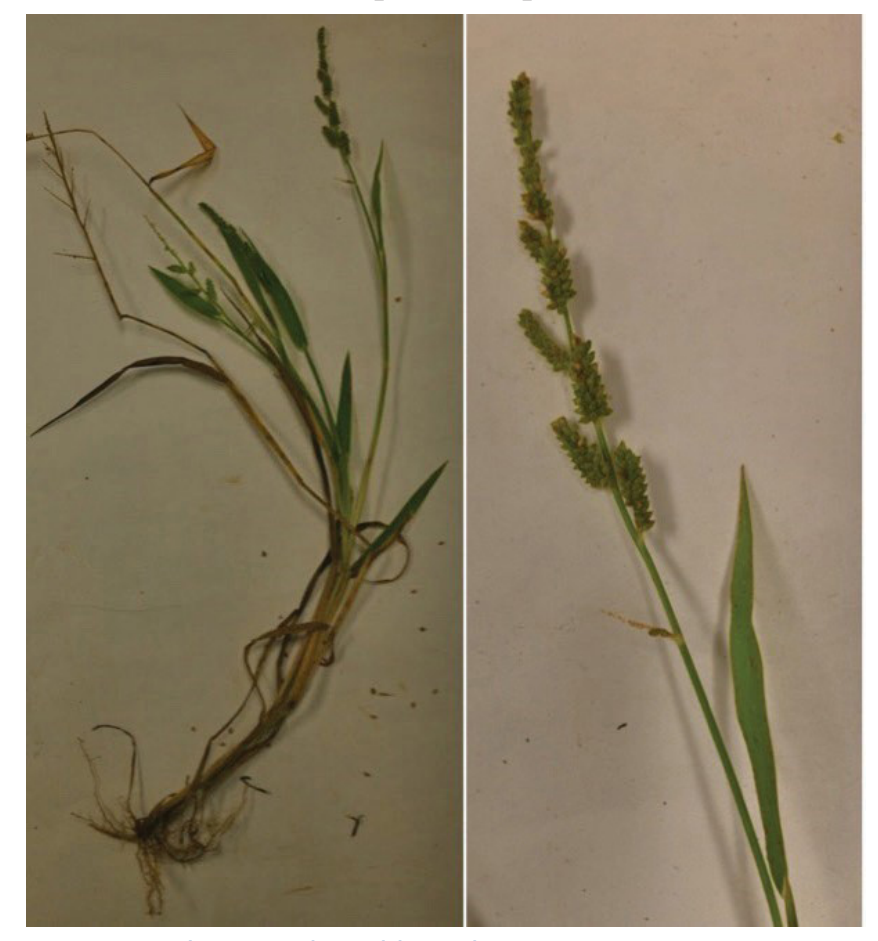

Figure 10. Jungle rice (Echinochloa colona).

Credits: Kingsley Wiggan 


\section{Goosegrass, Eleusine indica (L.) Gaertn. (Poaceae)}

This annual weed and turfgrass is common throughout Florida, but is native to regions of Asia, Europe, and/or Africa. It grows well in compact, wet soils and competes with both warm- and cool-season turfgrasses, especially in thin, open lawns. It is problematic due to its vigorous growth, abundant seed production, and tolerance of frequent mowing to short heights.

\section{Growth Habit}

This summer annual or short-lived perennial grows to 80 $\mathrm{cm}$; it often forms a low rosette of 3-12 flattened, nearly hairless stems (2-10 $\mathrm{mm}$ wide including leaf sheaths), which radiate outward.

\section{Leaves}

Blades are $2-50 \mathrm{~cm}$ long by $2-8 \mathrm{~mm}$ wide; they attach to sheaths that are 1-9 $\mathrm{cm}$ long, similarly broad, and often whitish to pale green with membranous, fringed ligules. Blades and sheaths are mostly hairless and usually folded or laterally flattened.

\section{Inflorescence}

Inflorescence consists of a terminal cluster of 2-14 flattened, shiny, finger-like spikes (1-14 cm long). Most of these emerge from a cluster near the tip of the inflorescence with 1-3 spikes attached below. Each spike is composed of 2 rows of stalkless (sessile), 3- to 5.5-mm spikelets, each with 3-5 highly reduced 2-3.5 $\mathrm{mm}$ flowers (florets); the spike resembles a goosefoot, hence the name.

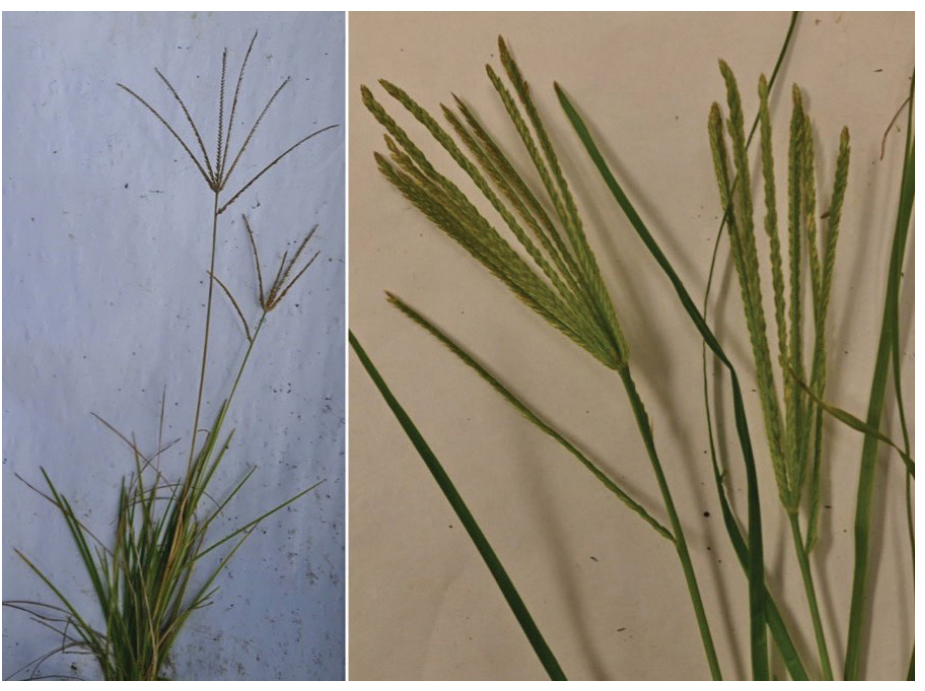

Figure 11. Goosegrass (Eleusine indica).

Credits: Kingsley Wiggan

\section{Mediterranean Lovegrass, Eragrostis barrelieri Daveau (Poaceae)}

Native to Europe, Mediterranean lovegrass is most common in Florida in highly disturbed locations such as in open, tilled rocky soil. The species can also be an attractive lawn grass. In agriculture, it readily takes advantage of any holes or tears in plastic mulch.

\section{Growth Habit}

This plant is a clump-forming, often fast-growing species that grows to $55 \mathrm{~cm}$ tall.

\section{Leaves}

Blades are small and fine-textured, 6-90 mm long, and 1-4 mm wide.

\section{Inflorescence}

Seed heads form in attractively branched panicles adorned with 2- to 15-mm spikelets. Each spikelet has 3-30 florets, each 1.3-1.7 mm long.

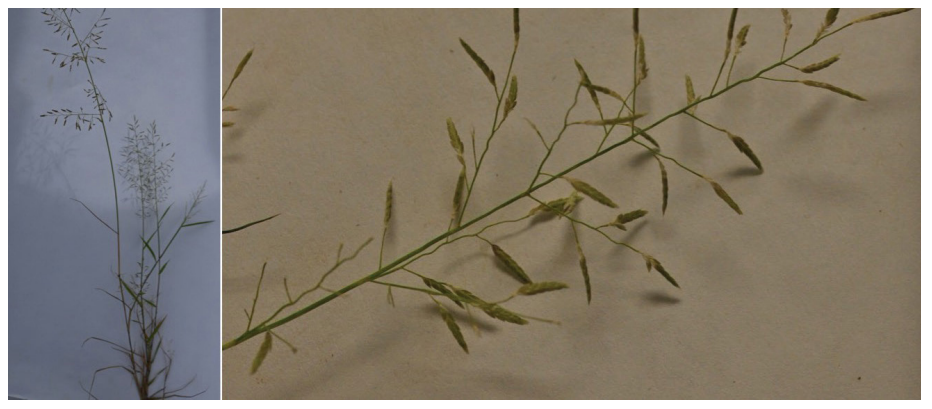

Figure 12. Mediterranean lovegrass (Eragrostis barrelieri). Credits: Kingsley Wiggan

\section{Itchgrass, Rottboellia cochinchinensis (Lour.) Clayton (Poaceae)}

This summer annual from Asia is similar to corn (Zea mays L.). Both species have relatively large florets for grasses, and the flowering racemes of itchgrass are thick and somewhat similar to very thin corncobs.

\section{Growth Habit}

Stems are erect, straight, and sometimes single; they grow $0.3-3 \mathrm{~m}(1-10 \mathrm{ft})$. 


\section{Leaves}

Leaf blades are flat, 5-60 $\mathrm{cm}$ long, and 5-30 $\mathrm{mm}$ wide. The leaf sheaths are hairy.

\section{Inflorescence}

This plant has a jointed, cylindrical raceme $2.5-15 \mathrm{~cm}$ long with embedded, 4- to 6-mm florets.

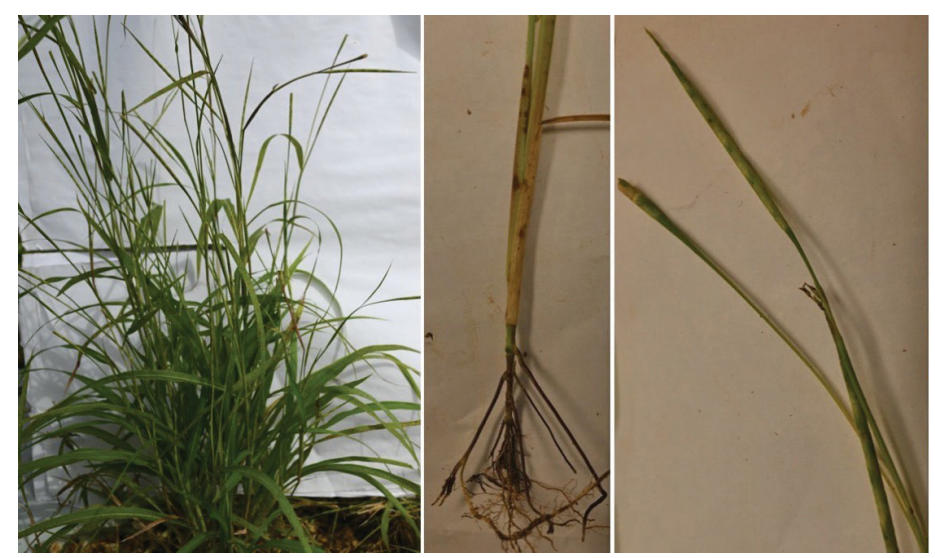

Figure 13. Itchgrass (Rottboellia cochinchinensis).

Credits: Kingsley Wiggan

\section{Further Reading}

Cultural, mechanical, and chemical control measures are available to manage weeds in competition with crops. Site selection, early monitoring, and reproductive disruption are critical for a strong weed management program. Control options are provided in other EDIS publications (https:// edis.ifas.ufl.edu/entity/topic/weeds).

For weed species not covered in this document, consult comprehensive guides, such as Weeds of Southern Turfgrasses (Murphy et al. 1992) and Florida Wildflowers and Roadside Plants (Bell and Taylor 1982). An effective technique for identifying weeds or other plant species involves using botanical keys and comparing the plant with online herbarium specimens. Steps to use a botanical key are available in EDIS publication ENH1249, How to Use a Dichotomous Key: A Tutorial Featuring 10 Common Shade Trees of the Tampa Bay Area (https://edis.ifas.ufl.edu/ ep510). Guide to the Vascular Plants of Florida (Wunderlin and Hansen 2011) has keys for identifying weeds and nonweeds that grow without cultivation in Florida as well as an excellent glossary of botanical terms. Online herbarium specimens are also available through the Atlas of Florida Plants (http://florida.plantatlas.usf.edu) and the University of Florida Herbarium Collections Catalog (http://www. flmnh.ufl.edu/herbarium/cat/catsearch.htm). The Florida Exotic Pest Plant Council publishes lists of the most invasive plant species (http://bugwoodcloud.org/CDN/fleppc/ plantlists/2019/2019_Plant_List_ABSOLUTE_FINAL.pdf).
An assessment of the invasiveness of non-native plants in Florida's natural areas may be found at https://assessment. ifas.ufl.edu/assessments/. Finally, plant specimens can be submitted to professional botanists for identification using instructions given by the UF/IFAS Plant Identification and Information Service (https://edis.ifas.ufl.edu/publication/ sr024).

\section{References}

Bell, C. R., and B. J. Taylor. 1982. Florida Wildflowers and Roadside Plants. Laurel Hill Press.

Boyd, N. S., K. Fnu, C. Marble, S. Steed, and A. W. MacRae. 2016. Biology and Management of Goosegrass (Eleusine indica (L.) Gaertn.) in Tomato, Pepper, Cucurbits, and Strawberry. HS1178. Gainesville: University of Florida Institute of Food and Agricultural Sciences. https://edis.ifas. ufl.edu/hs1178

Bracero, V., L. I. Rivera, and J. S. Beaver. 2003. “DNA Analysis Confirms Macroptilium lathyroides As Alternative Host of Bean Golden Yellow Mosaic Virus." Plant Disease 87(9): 1022-1025.

FAWN (Florida Automated Weather Network). 2019. "Data for the Tropical Research and Education Center (TREC), Homestead, Florida, Jul 1998 to Jun 2019 (excl. Jan-Dec 2000)." Accessed on July 24, 2019. http://fawn.ifas.ufl.edu/

FLEPPC (Florida Exotic Pest Plant Council). 2019. "List of Invasive Plant Species.” Accessed on August 22, 2019. http:// bugwoodcloud.org/CDN/fleppc/plantlists/2019/2019_ Plant_List_ABSOLUTE_FINAL.pdf

Haseler, W. H. 1976. "Parthenium hysterophorus in Australia.” Pest Articles and News Summaries 22(4): 515-517.

Koeser, A. K., G. Hasing, M. G. Andreu, and M. H. Friedman. 2018. How to Use a Dichotomous Key: A Tutorial Featuring 10 Common Shade Trees of the Tampa Bay Area. ENH1249. Gainesville: University of Florida Institute of Food and Agricultural Sciences. https://edis.ifas.ufl.edu/ ep510

Kohli, R. K., D. R. Batish, H. Singh, and K. S. Dogra. 2006. "Status, Invasiveness and Environmental Threats of Three Tropical American Invasive Weeds (Parthenium hysterophorus L., Ageratum conyzoides L., Lantana camara L.) in India.” Biological Invasions 8(7): 1501-1510. 
Li, Y. 2001. Calcareous Soils in Miami-Dade County. SL 183. Gainesville: University of Florida Institute of Food and Agricultural Sciences. https://edis.ifas.ufl.edu/tr004

McConnachie, A. J., L. W. Strathie, W. Mersie, L. Gebrehiwot, K. Zewdie, A. Abdurehim, B. Abrha, T. Araya, F. Asaregew, F. Assefa, and R. Gebre-Tsadik. 2011. "Current and Potential Geographical Distribution of the Invasive Plant Parthenium hysterophorus (Asteraceae) in Eastern and Southern Africa." Weed Research 51(1): 71-84.

Murphy, T. R., D. L. Colvin, R. Dickens, J. W. Everest, D. Hall, and L. B. McCarty. 1992. Weeds of Southern Turfgrasses. University of Georgia.

Nobel, C. V., R. W. Drew, and J. D. Slabaugh. 1996. Soil Survey of Dade County Area Florida. Washington, D.C.: Natural Resources Conservation Service, USDA. https:// www.nrcs.usda.gov/Internet/FSE_MANUSCRIPTS/florida/ FL686/0/Dade.pdf

Perkins, K., S. Haas, and P. Caplan (application development). 2021. "University of Florida Herbarium Collections Catalog." Gainesville: University of Florida. http://www. flmnh.ufl.edu/herbarium/cat/catsearch.htm

Radosevich, S. R., J. S. Holt, and C. Ghersa. 1997. Weed Ecology: Implications for Management. New York: John Wiley \& Sons.

Rodriguez, G. S., and G. S. Cepero. 1984. "Number of Seeds Produced by Some Weed Species." Centro Agricola 11(1): 45-50.

Rosario, J., C. Fuentes, R. De Prado, and H. Cruz. 2009. "Resistance of Parthenium hysterophorus L. to the Glyphosate: A New Case of Resistance in Colombia." XIIIème Colloque International sur la Biologie des Mauvaises Herbes, Dijon, France, 8-10 Septembre 2009: 397-404.

Seal, D., S. Zhang, M. Ozores-Hampton, P. Dittmar, Y. Li, W. Klassen, Q. Wang, and T. Olczyk. 2016. Summer Squash Production in Miami-Dade County, Florida. HS-861. Gainesville: University of Florida Institute of Food and Agricultural Sciences. https://edis.ifas.ufl.edu/tr012

Sellers, B., and J. Ferrell. 2018. Spiny Amaranth (Spiny Pigweed) Control in Pastures. SS-AGR-288. Gainesville: University of Florida Institute of Food and Agricultural Sciences. https://edis.ifas.ufl.edu/ag292
Stamps, R. H.2011. Identification, Impacts, and Control of Ragweed Parthenium (Parthenium hysterophorus L.). ENH1187. Gainesville: University of Florida Institute of Food and Agricultural Sciences. https://edis.ifas.ufl.edu/ ep448

Swearingen, J., and C. Bargeron. 2018. "Invasive Plant Atlas of the United States." University of Georgia Center for Invasive Species and Ecosystem Health. Accessed on August 5, 2019. https://www.invasiveplantatlas.org/subject. html? sub $=4568$

UF/IFAS. 2019. "Assessment of Non-Native Plants in Florida's Natural Areas." Accessed on August 22, 2019. https://assessment.ifas.ufl.edu/assessments/

Williams, N. H., and M. S. Frank. 2021. Request for Plant Identification. RFSR024. Gainesville: University of Florida Institute of Food and Agricultural Sciences. https://edis.ifas. ufl.edu/publication/sr024

Williams, J. D., and R. H. Groves. 1980. “The Influence of Temperature and Photoperiod on Growth and Development of Parthenium hysterophorus." Weed Research 20(1): 47-52.

Wunderlin, R. P., and B. F. Hansen. 2011. Guide to the Vascular Plants of Florida, Third Edition. Gainesville: University Press of Florida.

Wunderlin, R. P., B. F. Hansen, A. R. Franck, and F. B. Essig. 2021. "Atlas of Florida Plants." (S. M. Landry and K. N. Campbell, application development, USF Water Institute.) Institute for Systematic Botany, University of South Florida, Tampa. http://florida.plantatlas.usf.edu 